\title{
Corrigendum: A Survey of Consumer Perceptions of Plant-Based and Clean Meat in the USA, India, and China
}

\author{
Christopher Bryant ${ }^{1 *}$, Keri Szejda ${ }^{2}$, Nishant Parekh ${ }^{2}$, Varun Deshpande ${ }^{2}$ and Brian Tse ${ }^{3}$ \\ ${ }^{1}$ Department of Psychology, University of Bath, Bath, United Kingdom, ${ }^{2}$ The Good Food Institute, Washington, DC, \\ United States, ${ }^{3}$ Center for Long Term Priorities, Hong Kong, China
}

Keywords: clean meat, cultured meat, cell-based meat, plant-based meat, consumer acceptance, consumer behavior

\section{A Corrigendum on}

\section{OPEN ACCESS}

Edited and reviewed by:

Cor Van Der Weele,

Wageningen University and

Research, Netherlands

*Correspondence:

Christopher Bryant

c.j.bryant@bath.ac.uk

Specialty section

This article was submitted to Climate-Smart Food Systems,

a section of the journal

Frontiers in Sustainable Food Systems

Received: 30 January 2020

Accepted: 14 May 2020

Published: 23 June 2020

Citation:

Bryant C, Szejda K, Parekh N,

Deshpande $V$ and Tse B (2020)

Corrigendum: A Survey of Consumer Perceptions of Plant-Based and Clean

Meat in the USA, India, and China.

Front. Sustain. Food Syst. 4:86.

doi: 10.3389/fsufs. 2020.00086
A Survey of Consumer Perceptions of Plant-Based and Clean Meat in the USA, India, and China by Bryant, C., Szejda, K., Parekh, N., Desphande, V., and Tse, B. (2019). Front. Sustain. Food Syst. 3:11. doi: 10.3389/fsufs.2019.00011

An author's name was incorrectly spelled as "Varun Desphande." The correct spelling is "Varun Deshpande".

In addition, the percentage of consumers in India who were willing to consume cultured meat was slightly under-reported. This was due to human error caused by reading numbers from the wrong column of a table.

A correction has been made to the Results section, subsection Descriptive Statistics, subsubsection Acceptance, paragraph 1:

"We see a similar pattern with regards to purchase likelihood, which was also substantially higher in China and India compared to in the USA. In the USA, 23.6\% were not at all likely to purchase clean meat; $46.6 \%$ were somewhat or moderately likely, and $29.8 \%$ were very or extremely likely. In China, $6.7 \%$ were not at all likely to purchase clean meat; $33.9 \%$ were somewhat or moderately likely, and 59.3\% were very or extremely likely. In India, $10.7 \%$ were not at all likely to purchase clean meat; $32.9 \%$ were somewhat or moderately likely, and $56.3 \%$ were very or extremely likely."

The authors apologize for this error and state that this does not change the scientific conclusions of the article in any way. The original article has been updated.

Copyright (0) 2020 Bryant, Szejda, Parekh, Deshpande and Tse. This is an open-access article distributed under the terms of the Creative Commons Attribution License (CC BY). The use, distribution or reproduction in other forums is permitted, provided the original author(s) and the copyright owner(s) are credited and that the original publication in this journal is cited, in accordance with accepted academic practice. No use, distribution or reproduction is permitted which does not comply with these terms. 